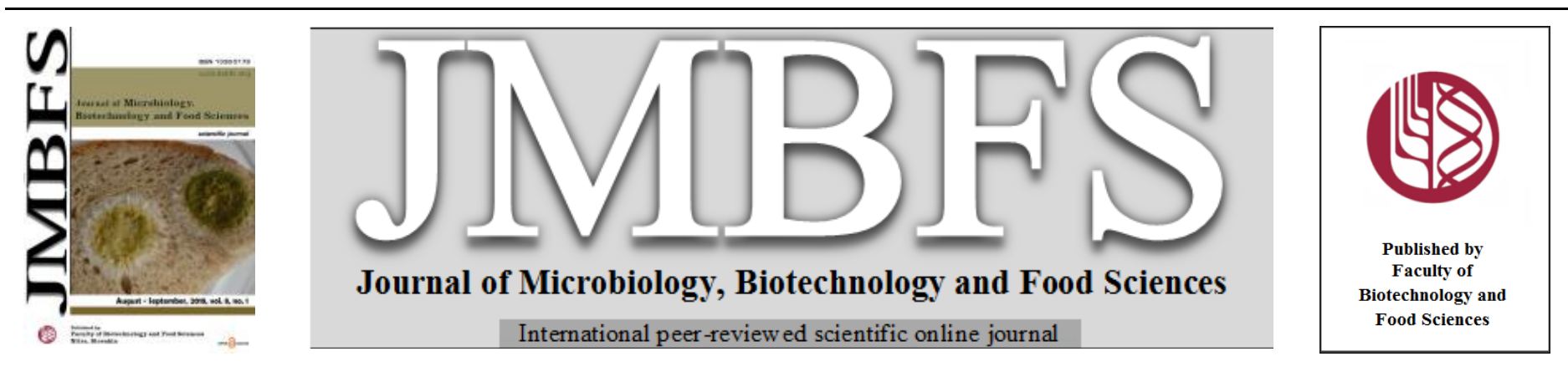

\title{
IDENTIFICATION OF LIPASE PRODUCING FUNGUS ISOLATED FROM DAIRY WASTE CONTAMINATED SOIL AND OPTIMIZATION OF CULTURE CONDITIONS FOR LIPASE PRODUCTION BY THE ISOLATED FUNGUS
}

\author{
Madonna Roy ${ }^{1}$, RupeshKumar ${ }^{2}$, Anand Ramteke ${ }^{2}$, Nandan Sit ${ }^{1, *}$ \\ Address(es): \\ ${ }^{1}$ Department of Food Engineering and Technology, Tezpur University, Assam-784028, India. \\ ${ }^{2}$ Department of Molecular Biology and Biotechnology, Tezpur University, Assam-784028, India.
}

*Corresponding author: nandansit@yahoo.co.in

doi: $10.15414 / j m b f s .2018 .8 .1 .698-704$

\section{ARTICLE INFO}

Received 6. 5. 2018

Revised 25. 6. 2018

Accepted 2. 7. 2018

Published 1. 8. 2018

Regular article

oPEN $\partial_{\text {ACCESS }}$

\section{ABSTRACT}

Fungal strain from dairy waste contaminated soil was isolated for lipase production. The isolated strain was checked for lipase production and the species was identified morphologically by SEM and phylogenetically by NCBI-BLAST analysis. The culture conditions for production of lipase using the isolated fungus with mustard oil as substrate were optimized for obtaining maximum lipase activity and biomass by response surface methodology. Morphological identification and NCBI-BLAST analysis revealed the fungal strain to be of Aspergillus aculeatus. The optimum culture conditions were $1 \%$ mustard oil concentration, incubation temperature of 35 ${ }^{\circ} \mathrm{C}$ and incubation time of $214.74 \mathrm{~h}$. The lipase activity and biomass at the optimized condition were $9.51 \mathrm{U} / \mathrm{ml}$ and $549.88 \mathrm{mg}$ respectively. It can be concluded from the present study that the strain of the fungus Aspergillus aculeatus isolated from dairy waste contaminated soil can be potentially used to produce lipase.

Keywords: Dairy Waste; Fungus; Isolation; Identification; Lipase production; Optimization

\section{INTRODUCTION}

The demand for industrial enzymes, particularly of microbial origin, is ever increasing owing to their applications in a wide variety of processes. In recent years lipases have gained importance over proteases and amylases, especially in the area of organic synthesis (Sivakumar, 2014). The enantioselective and regioselective nature of lipases have been utilized for the resolution of chiral drugs, fat modification, synthesis of cocoa butter substituents, biofuels, and for synthesis of personal care products and flavour enhancers (Sundar and Kumaresapillai, 2013).

Lipase or triacylglycerol acylhydrolases are hydrolytic enzymes which break down triacylglycerides into free fatty acids and glycerols. Naturally, the substrates of lipases are triacylglycerols which have very low solubility in water. In normal conditions lipases catalyse the hydrolysis of ester bonds and the reaction takes place at the interface between an insoluble substrate phase and the aqueous phase in which the enzyme is dissolved. Under certain experimental conditions they are capable of reversing the reaction, e.g. such as in the absence of water. Esterification of fatty acids with glycerol and formation of glycerides takes place due to the reversed reaction. Lipases are ubiquitous enzymes which are widely distributed in plant, animal and microbial world. Among lipases of plant, animal and microbial origin, it is the microbial lipases that finds immense application. Microbial lipase are preferred because they offer great variety of catalytic activities, high yields, ease of genetic manipulation, rapid growth on inexpensive media, regular supply and are not affected by seasonal fluctuations Microbial lipases have also gained special industrial attention due to their stability, selectivity, and broad substrate specificity (Dutra et al., 2008; Griebeler et al., 2011).

Lipase-producing microorganisms have been found in diverse habitats such as industrial wastes, vegetable oil processing factories, dairies, soil contaminated with oil, oilseeds, and decaying food, compost heaps, coal tips, and hot springs (Muthazhagan and Thangaraj, 2014). Fungi, yeast and bacteria are three main sources of microbial lipase for industrial production. Fungal lipases are particularly important in industrial applications (Nwuche and Ogbonna, 2011). Earlier also researchers have isolated and identified various lipase producing bacterial (Veerapagu et al., 2013; Rajeshkumar et al., 2013; Sirisha et al., 2010) and fungal (Üllker et al., 2011; Fan et al., 2013; Griebeler et al., 2011; Colen et al., 2006; Nwuche and Ogbonna, 2011) strains from oil or lipid contaminated soils and other sources for lipase production. The conditions for lipase production have also been optimized (Sirisha et al., 2010; Falony et al.,
2006; Veerapagu et al., 2013), and few works on using response surface methodology for optimization (Salihu et al. 2011; Açıel et al., 2010; Vargas et al. 2008; Hosseinpour et al., 2012) are also reported, but most of the works were on optimizing solid state fermentation process.

The knowledge of new microorganisms capable of producing lipase, new supplements and substrates for lipase production along with knowledge of operational conditions will be very much helpful in achieving the best combinations for high value lipase production and lower the production costs in industrial processes (Falony et al., 2006; Salihu et al., 2011). In this regard, the present study focussed on lipase producing microorganisms that would be naturally present in a particular environment, and dairy waste contaminated soil would be one of them. As dairy wastes contain substantial amount of dairy fats, therefore probability of having lipase producing fungi in this type of soil is high. Therefore, the objectives of this study are to isolate and identify a fugal species from soil contaminated with dairy waste and to optimize the culture conditions for lipase production using the isolated fungus.

\section{MATERIALS AND METHODS}

\section{Soil sample collection}

Soil sample contaminated with dairy waste was collected from near the dairy processing unit of "Spring Valley Bakery" in Tezpur town, Assam, India. The samples were scooped with a clean spatula into airtight sterile plastics and labelled appropriately. They were then transported to the laboratory for analysis. The isolation of the fungal cultures was carried out within 6 to 48 hours after sampling.

\section{Reagents and chemicals}

PCR buffer (Invitrogen, North America), dNTP mix (Invitrogen, North America), $\mathrm{MgCl}_{2}$ (Invitrogen, North America), Taq DNA Polymerase (Invitrogen, North America), DNA template, PCR water (HiMedia, Mumbai, India), ITS1-F and ITS4-R primers (Biolinkk, New Delhi, India), Agarose (Invitrogen, North America), 1x TAE Buffer (HiMedia, Mumbai, India), Electrophoretic System (Genei, Bangalore), Blue juice (Loading buffer, Invitrogen, North America), DNA Sample (PCR products), DNA Marker (100 bp ladder, Invitrogen, North America). All other chemical used were of analytical grade or molecular biology grade. 


\section{Isolation of fungus}

The fungal organism present in the soil sample was isolated by serial dilution and agar plating and by inhibiting the growth of bacterial cells by adding $10 \%$ tartaric acid to PDA medium (Apinis, 1963). Molds and yeasts were identified and moulds were isolated from the PDA plate. The fungal isolate was then subcultured to a new PDA plate and incubated at $27^{\circ} \mathrm{C}$ for $24-48 \mathrm{~h}$. After $48 \mathrm{~h}$ of incubation the fungal isolates were stored in refrigerator.

\section{Microscopic examination}

The isolated fungal strain was observed under microscope at $40 \mathrm{X}$ magnification after staining with lactophenol cotton blue (LPCB)

\section{Evaluation of lipase production}

Confirmation of lipase production by the isolated fungal strain was done using two methods, by inoculating the microorganism in Tween 80 agar plate containing phenol red indicator and in Tributyrin agar plates (Aoyama, 1988).

\section{Identification of the fungal strain}

\section{Morphological characteristics by scanning electron microscope (SEM)}

Scanning electron microscopic (SEM) image of the isolated fungus was obtained at different magnification to study the morphological characteristics. Fresh culture was taken in an Eppendorf tube. PBS buffer $(500 \mu 1)$ was added to the culture. The Eppendorf tube was centrifuged at $8000 \mathrm{rpm}$ for $15 \mathrm{~min}$. This step was repeated three times. Small amount of the pellet was transferred to a new Eppendorf tube. One (1) $\mathrm{ml}$ of $2.5 \%$ glutaraldehyde was added to the pellet and mixed. It was then incubated overnight at $4^{\circ} \mathrm{C}$. PBS buffer $(500 \mu 1)$ was added to the culture and centrifuged at $8000 \mathrm{rpm}$ for $15 \mathrm{~min}$. The supernatant was discarded. The pellet was washed with $1 \mathrm{ml}$ of $35 \%, 50 \%, 75 \%, 90 \%, 95 \%, 100 \%$ ethanol by centrifuging the sample at $3000 \mathrm{rpm}$ for $10 \mathrm{~min}$. After the last wash with $100 \%$ ethanol, $20 \mu \mathrm{l}$ of the sample was placed in a cover slip and allowed to dry for the removal of ethanol. After dehydration, the specimens were mounted on the aluminium specimen holder by double-sided tape. The samples were coated with platinum and examined under the microscope at an accelerating voltage of $15 \mathrm{kV}$ at different magnifications.

\section{Phylogenetic characterization}

Genomic DNA was extracted with the established CTAB method (Wu et al., 2001). After isolation of DNA, quantification and analysis of quality of DNA sample using NanoDrop spectrophotometer (NanoDrop 2000, Thermo Fisher, Wilmimgton, USA) was carried out. The ratio of the absorbance at 260 and $280 \mathrm{~nm}\left(\mathrm{~A}_{260 / 280}\right)$ was used to assess the purity of nucleic acids. For pure DNA, $\mathrm{A}_{260 / 280}$ is 1.8 (Glasel, 1995)

The 18SrDNA was amplified by PCR using primer ITS1-F (5'TCCGTAGGTGAACCTGCGG-3') and ITS4-R (5'TCCTCCGCTTATTGATATGC-3'). Reaction mixture of $25 \mu 1$ was composed of $2.5 \mu 1$ 10x PCR buffer, $0.5 \mu \mathrm{l}$ of $10 \mathrm{mMdNTP}$ mix, $1.2 \mu 125 \mathrm{mM} \mathrm{MgCl}_{2}, 0.8 \mu$ Taq DNA Polymerase, $1.2 \mu \mathrm{l}$ Glycerol, $0.5 \mu \mathrm{l}$ of Forward and Reverse Primers, $4.0 \mu 1$ of DNA Template and PCR water. The PCR cycle parameters included initial denaturation at $94^{\circ} \mathrm{C}$ for $5 \mathrm{~min}$, followed by 40 cycles of denaturation $\left(94^{\circ} \mathrm{C}, 30 \mathrm{~s}\right)$, annealing $\left(56.5^{\circ} \mathrm{C}, 30 \mathrm{~s}\right)$, extension $\left(72^{\circ} \mathrm{C}, 30 \mathrm{~s}\right)$, and final extension at $72^{\circ} \mathrm{C}$ for $7 \mathrm{~min}$ (Veriti ${ }^{\circledR}$ Thermal Cycler, Applied Biosystems, Foster City, USA).The amplified product was electrophoresed on $2 \%$ agarose ge along with DNA molecular weight marker (Quick-load ${ }^{\mathrm{TM}} 100 \mathrm{bp}$ DNA ladder Invitrogen, North America). Gel was stained with ethidium bromide and visualized over Gel Documentation System. Sequencing of the purified DNA obtained from ITS-PCR was performed in Sequencer (Genetic Analyzer, Applied Biosystems) by Sanger sequencing method (Sanger and Coulson, 1975). The nucleotide sequences were subjected to BLAST analysis on (http://www.ncbi.nih.gov/ index.html). Phylogenetic trees were constructed and the fungal strain was identified. The sequences were submitted to Gene Bank at NCBI database and accession numbers were obtained.

\section{Lipase production}

The identified fungal cultures maintained in PDA plates were grown in inoculation medium containing glucose $(10 \mathrm{~g} / \mathrm{l})$, peptone $(20 \mathrm{~g} / \mathrm{l})$, sodium chloride $(5 \mathrm{~g} / \mathrm{l})$ and yeast extract $(5 \mathrm{~g} / \mathrm{l})$ at $\mathrm{pH}$ 6.0. Cultures (72 h old) were prepared as spore suspension by adding $5 \mathrm{ml}$ sterile water. This $5 \mathrm{ml}$ of spore suspension was added with $45 \mathrm{ml}$ of inoculum medium in $100 \mathrm{ml}$ Erlenmeyer flasks. The total contents were incubated in rotary shaker at $30^{\circ} \mathrm{C}$ for $48 \mathrm{~h}$. The prepared inoculum $(10 \%)$ were transferred to production medium which consists of inoculation medium supplemented with salt solution containing ammonium sulphite $(5 \mathrm{~g} / \mathrm{l})$, sodium hydrogen phosphate $(6 \mathrm{~g} / \mathrm{l})$, potassium hydrogen phosphate $(2 \mathrm{~g} / \mathrm{l})$, magnesium sulphate (3 g/l) and calcium chloride (3 g/l) (Sundar and
Kumaresapillai, 2013). The carbon source glucose in the production medium was substituted by different concentrations of mustard oil as per design. The production medium was then incubated for different time and temperature as per experimental design for lipase production.

\section{Determination of lipase activity}

Lipase activity assay was done as per standard method by titrimetric using olive oil as a substrate (Jensen, 1983). Lipase activity was determined by incubating a reaction mixture containing $5 \mathrm{ml}$ of olive oil emulsion, $2 \mathrm{ml}$ of $0.1 \mathrm{M}$ phosphate buffer, $\mathrm{pH} 7.0$ and $1.0 \mathrm{ml}$ of the culture filtrate (lipase crude extract) at $37^{\circ} \mathrm{C}$ for $30 \mathrm{~min}$, with shaking of $130 \mathrm{rpm}$. After incubation, the reaction was stopped by the addition of $15 \mathrm{ml}$ of acetone-ethanol (1:1) and the liberated free fatty acids were titrated with $0.05 \mathrm{~N} \mathrm{NaOH}$ in the presence of phenolphthalein as indicator. One unit of lipase activity was calculated as the amount of enzyme liberating one micro mole of fatty acid per minute under standard assay conditions.

$$
\begin{aligned}
\text { Lipase activity }(\mathrm{U} / \mathrm{ml} / \mathrm{min}) & =\frac{\text { volume of } \mathrm{NaOH} \text { consumed in } \mathrm{ml} \times \text { Normality of } \mathrm{NaOH}}{\text { time of incubation in } \mathrm{min} \times \text { volume of enzyme solution in } \mathrm{ml}} \\
& \times 1000
\end{aligned}
$$

\section{Determination of Biomass}

For biomass determination, the culture supernatant was separated from the mycelium by filtration through an already weighed Whatmann filter paper (Sharma et al., 2001). The biomass was washed many times with distilled water and then dried at $80^{\circ} \mathrm{C}$, for around $18-24$ hours, and was weighed until constant weight was obtained.

$$
\text { Biomass }(\mathrm{mg} / \mathrm{ml})=\frac{\text { weight of filter paper with biomass }- \text { weight of empty filter paper }}{\text { volume of sample in } \mathrm{ml}}
$$

\section{Experimental design for optimization of culture conditions}

A Box-Behnken Design (BBD) with three numerical factors was employed to design the experiments. The numerical factors were substrate i.e. mustard oil concentration $(\mathrm{C})$, temperature of incubation $(\mathrm{T})$ and incubation time ( $\mathrm{t}$ ). Mustard oil was selected as a substrate as it is abundantly produced and consumed in the North-East region of India and may be useful for development interesterified products which might be useful for the people of this region. The substrate concentration was varied from 1 to $\%$, incubation time was varied from 120 to $216 \mathrm{~h}$ and temperature was varied from 25 to $35^{\circ} \mathrm{C}$. A total of 17 experiments were performed (Table 1). Five experiments at the centre points of the design were performed to allow the estimation of pure error. All experiments were carried out in a randomized order to minimize the effect of external factors. Response surfaces were generated to study the effect of interactions of various culture conditions on lipase activity and biomass production.

\section{Data analysis and optimization}

Design Expert version 8 was used for analysis of data for the responses and optimization. Experimental data were fitted to a second order polynomial model as follows:

$$
Y=\beta_{o}+\sum_{i=1}^{3} \beta_{i} X_{i}+\sum_{i=1}^{3} \beta_{i i} X_{i}^{2}+\sum \sum_{i<j=1}^{3} \beta_{i j} X_{i} X_{j}
$$

Where $Y$ represents the response i.e. lipase activity or biomass, $\beta_{o}$, is the constant $\beta_{i}, \beta_{i i}$ and $\beta_{i j}$ are the regression coefficients and $X_{i}$ and $X_{j}$ are the independent variables in coded values.

Significant terms in the model were found by analysis of variance (ANOVA) Model adequacy was checked by lack of fit test, $\mathrm{R}^{2}$, predicted $\mathrm{R}^{2}$, adequacy precision and predicted residual sum of squares (PRESS). A non-significant ( $p>$ 0.05 ) lack of fit, predicted $\mathrm{R}^{2}$ comparable to fitted $\mathrm{R}^{2}$, low PRESS and adequacy precision higher than 4 , shows that the model fitted is adequate to predicting (Corzo et al. 2008; Mohapatra and Bal, 2010).

The optimization of the lipase production was done using desirability function.

\section{RESULTS AND DISCUSSION}

\section{Microscopic Observation and confirmation of lipase production by the isolated fungus}

The isolated and sub-cultured fungus formed brown-black coloured colony and back spores were observed in the PDA plate. Lactophenol cotton blue slide mounts of the isolated fungus was observed under phase contrast microscope. It is the most widely used method of staining and observing fungi. Hyphae and spores were clearly visible under the microscope (Figure 1). Conidiophores were seen which could mean that the isolated fungus might be ascomycetes. 


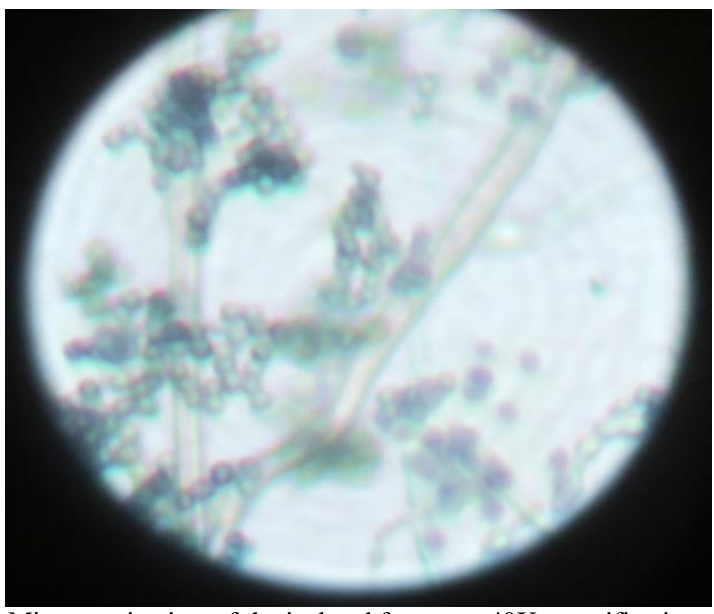

Figure 1 Microscopic view of the isolated fungus at $40 \mathrm{X}$ magnification

The isolated fungal strain was cultured in Tween 80 agar plate containing phenol red indicator as well as in tributyrin agar plate to see whether the strain produces lipase or not. Both the tests gave positive results for lipase production. A change in colouration from pink to yellow was observed in Tween 80 agar plate whereas a clear zone of hydrolysis was seen in tributyrin agar plate confirming the production of lipase by the isolated fungal strain.

\section{Identification of the isolated fungus}

The SEM images of the hyphae along with the spores of the isolated fungal strain are shown in Figure 2. Observations of SEM images of the isolated fungi revea swollen vesicle and ellipsoidal to subglobose or globose conidia which were found to resemble Aspergillus japonica as observed by Al-Musallam (1980).
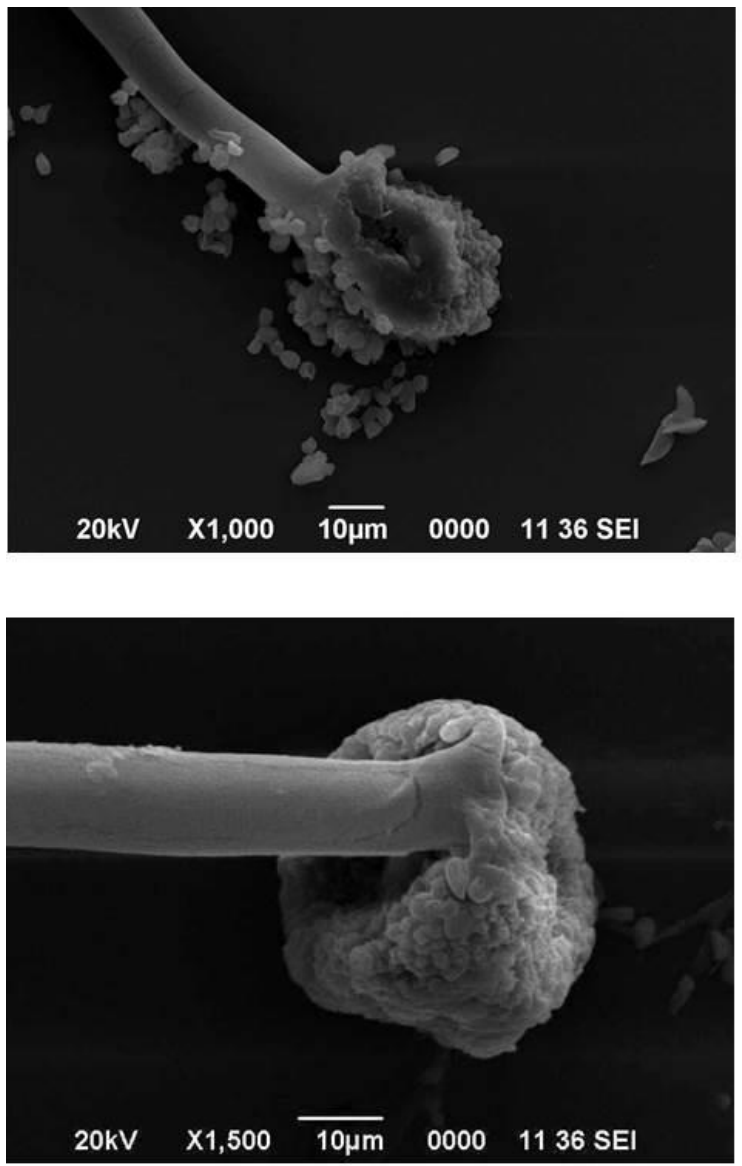

Genomic DNA of the fungus was successfully isolated by the CTAB method. The isolation of the genomic DNA was confirmed by DNA quantification using NanoDrop. Quantification of the DNA was done to quantify and analyse the quality of DNA to ascertain the approximate quantity of DNA obtained and the suitability of DNA sample for further analysis. The ratio of the absorbance at 260 and $280 \mathrm{~nm}\left(\mathrm{~A}_{260 / 280}\right)$ is used to assess the purity of nucleic acids. For pure DNA, $\mathrm{A}_{260 / 280}$ is approximately 1.8 (Glasel, 1995). From DNA quantification the pure DNA samples were selected. The rest of the samples were found to be contaminated with other molecules (i.e. proteins, organic compounds, other). Genomic DNA was successfully amplified by PCR using the ITS primer pair. PCR products generated from soil samples using the ITS primer pair were run on a $2 \%$ agarose gel. The size of the target amplicon of isolated fungus corresponds to $600 \mathrm{bp}$ as represented by the $100 \mathrm{bp}$ DNA ladder molecular size marker (Invitrogen, North America) (Figure 3).The species identity of the fungus was determined based on the alignment of their sequenced ITS regions with published sequences in the NCBI (National Center for Biotechnology Information) database. After sequencing, similarity search for the sequence data obtained was performed using BLAST (Basic Local Alignment Tool). BLAST result revealed the species identity of the unknown fungus to be Aspergillus aculeatus. The BLAST search for homologues for the fungus isolated in the study yielded results that had an identity of $97 \%$ and query coverage of $92 \%$. As inferred from the phylogenetic trees, the query fungus was very closely related to different Aspergillu saculeatus strains. Both the trees, Max likelihood (Figure 4a)) and Max parsimony (Figure 4b)) had a bootstrap value of 100\% which indicates to the high reproducibility of the tree. The tree can hence be considered consistent over 100 iterations. Hence it can be concluded that the isolated fungi is a strain of Aspergillus aculeatus. On the basis of sequencing report obtained, the isolated fungus was characterized as Aspergillus aculeatus and was designated as strain MRNS_TU (gb KR758756).
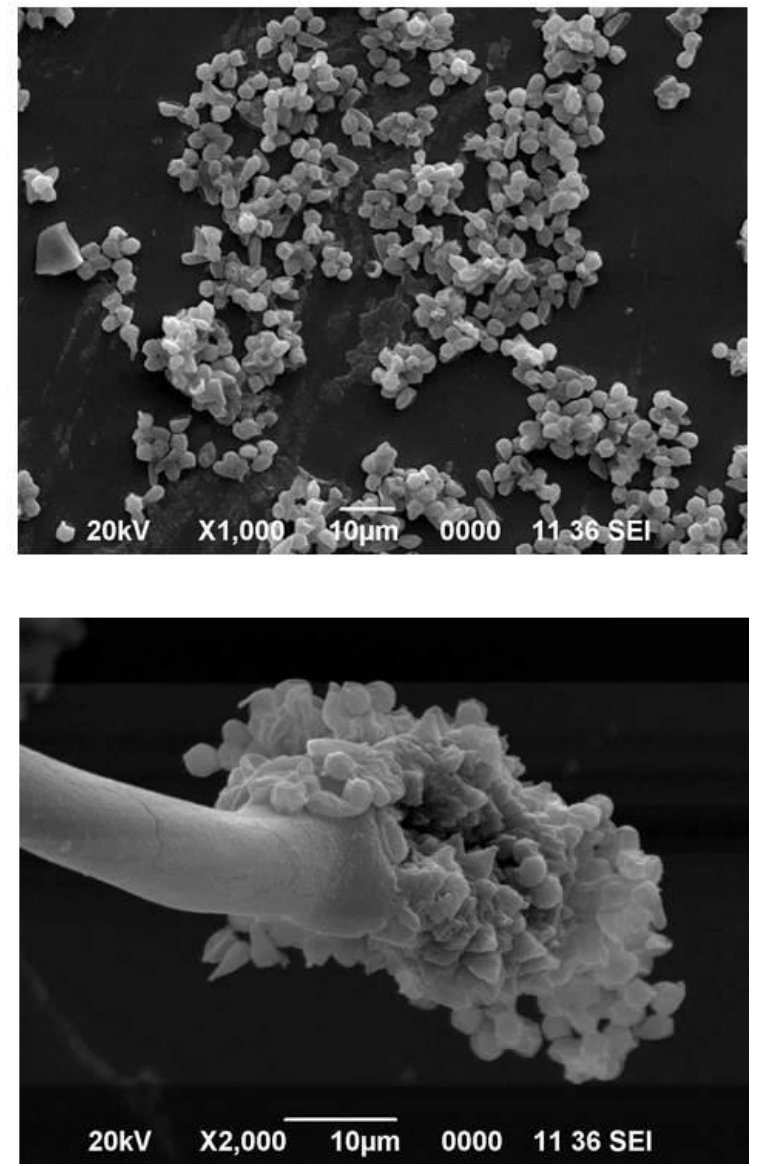

Figure 2 SEM images of the isolated fungus with hyphae and spores at different magnification 


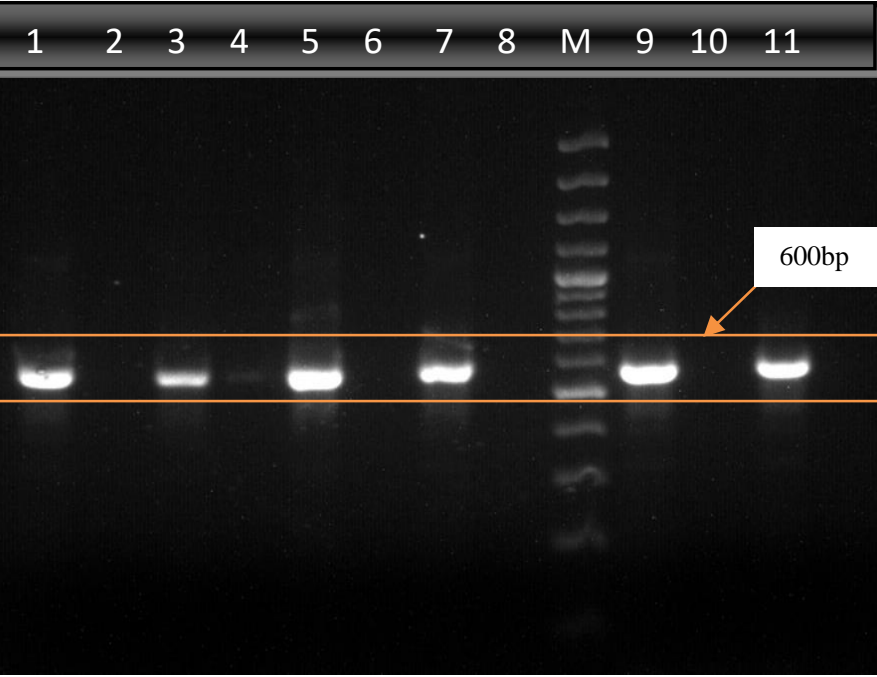

Figure 3 The size of the amplified targetamplicon of extracted DNA as represented in 1 XTAE $2 \%$ agarose gel. Lane $1,3,5,7,9,11$ are positive i.e. containing the amplified DNA and lane 2, 4, 6, 8, 10 are negative i.e. controls without any sample. Lane M shows the 100bp DNA ladder molecular size marke

(a)

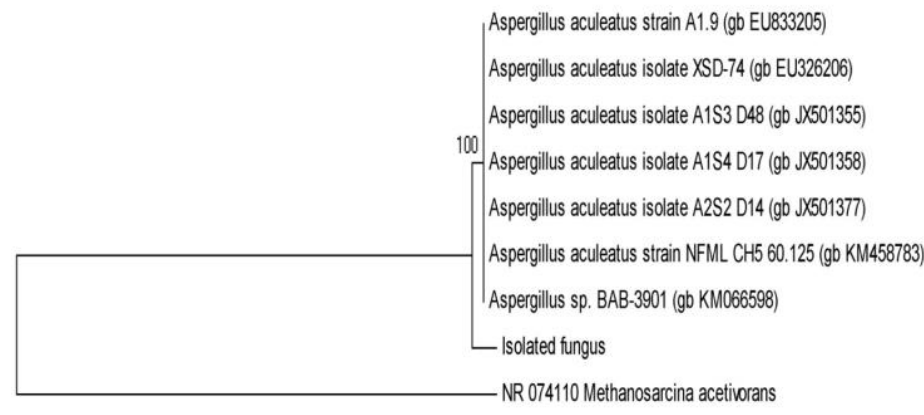

(b)

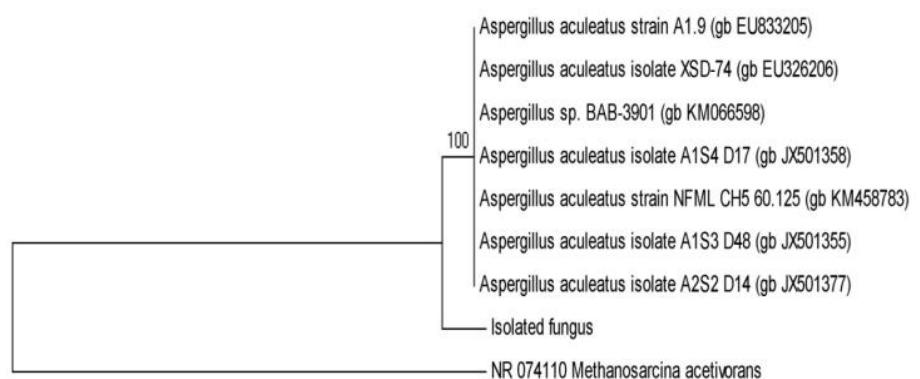

50

Figure 4 The maximum likelihood (a) and maximum parsimony (b) phylogenetic trees were constructed and bootstrapped (100 iterations) using robust phylogenetic analysis to represent the relationship between the isolated fungus and respective species of the genus Aspergillusand related genera. Bootstrap value is noted on the branch and the scale bar represents nucleotide substitution per 100 nucleotide.

Effect of culture conditions of Aspergillus aculeatus on the lipase activity and cell biomass

The values of lipase activity and cell biomass for different experimenta conditions are presented in Table 1. Second order polynomial equations were obtained for lipase activity and cell biomass by multilinear regression analysis of the experimental data. To determine the significant effects of the process variables on responses, analysis of variance (ANOVA) was performed Regression coefficients of the different terms in the equations for lipase activity and cell biomass in coded factors were obtained (Table 2). Model adequacy was checked by lack of fit test and by considering fitted $\mathrm{R}^{2}$, predicted $\mathrm{R}^{2}$, PRESS and adequacy precision. Coefficient of determination, $\mathrm{R}^{2}$, is defined as the ratio of the explained variation to the total variation and is a measure of the degree of fit (Haber and Runyon, 1977). It is also the proportion of the variability in the response variables, which is accounted for by the regression analysis (Mclaren $\boldsymbol{e}$ al., 1977). When $\mathrm{R}^{2}$ approaches unity, the better the empirical model fits the actual data. Smaller values of $\mathrm{R}^{2}$ show less relevance of the dependent variables in the model and could not explain the variation. Further, a non- significant $(p>$ 0.05 ) lack of fit, predicted $\mathrm{R}^{2}$ comparable to fitted $\mathrm{R}^{2}$, low PRESS and adequacy precision higher than 4 , implies that the model fitted is adequate to predicting (Corzo et al., 2008)

It can be observed from Table 2 that the probability $(p)$ values of all the main factors, quadratic term for temperature $\left(\mathrm{T}^{2}\right)$ and interaction of time and temperature i.e. $\mathrm{T} \times \mathrm{t}$ for the lipase activity were significant at $p<0.05$ and the model has non - significant lack of fit $(p>0.05)$, which is good, and also the adequacy precision for the model was more than 4 . The $\mathrm{R}^{2}$ value of the mode was 0.99 , whereas the adjusted $\mathrm{R}^{2}(0.98)$ and predicted $\mathrm{R}^{2}(0.96)$ were comparable indicating that the model fitted provided appropriate approximation of the true process.

Similarly, for the model of biomass production it was observed that the probability $(p)$ values of incubation time and incubation temperature among the main factors, quadratic term for incubation time $\left(\mathrm{t}^{2}\right)$ and temperature $\left(\mathrm{T}^{2}\right)$ and interaction of time and temperature i.e. $\mathrm{T} \times \mathrm{t}$ for the lipase activity were significant at $p<0.05$ and the model has non - significant lack of fit $(p>0.05)$. The adequacy precision for the biomass model was more than 4 . The $\mathrm{R}^{2}$ value of the model was 0.96 , whereas the adjusted $R^{2}(0.90)$ and predicted $R^{2}(0.65)$.

The final equations in terms of coded factors are as follows:

Lipase activity, $\mathrm{L}=6.26+1.71 \mathrm{~T}+0.27 \mathrm{t}-0.14 \mathrm{C}+0.92 \mathrm{~T}^{2}+0.04 \mathrm{t}^{2}+0.07 \mathrm{C}^{2}+0.19 \mathrm{~T}$ $\times \mathrm{t}+0.05 \mathrm{~T} \times \mathrm{C}+0.05 \mathrm{t} \times \mathrm{C}$

Biomass, $\mathrm{B}=584.00+79.88 \mathrm{~T}+58.13 \mathrm{t}+4.75 \mathrm{C}-80.63 \mathrm{~T}^{2}-44.13 \mathrm{t}^{2}-1.88 \mathrm{C}^{2}-$ $48.25 \mathrm{~T} \times \mathrm{t}+15.00 \mathrm{~T} \times \mathrm{C}-21.00 \mathrm{t} \times \mathrm{C}$

Response surface plots were generated to study the effect of various parameters on the lipase activity and biomass production during fermentation. The effect of interaction of various factors on lipase activity is shown in Figure 5. Figure 5 a) shows the variation in lipase activity with time and temperature during fermentation. Variation in lipase activity could not be observed with time at lower temperature. But, as the temperature increased, slight variation in the lipase activity was seen with variation in time. The lipase activity was found to increase with increase in temperature. Initially the change was slower at lower temperatures, but as the temperature was increased the lipase activity increased at a faster rate. The increase in lipase activity at higher temperature could be due to the fact that at low temperature the growth of the microorganism was slower compared to that at higher temperature, thereby producing less lipase and when the temperature increased the microorganism could grow at a faster rate and produced more lipase. Another reason could be that the optimum temperature for growth of the fungus and lipase production might be near $35^{\circ} \mathrm{C}$. Various authors have earlier reported that the activity of lipase produced by various fungal species was highest near $30{ }^{\circ} \mathrm{C}$ (Vargas et al., 2008; Kempka et al., 2007).

Figure 5 b) shows the interaction of incubation time and concentration. It was observed that lipase activity decreased with increase in concentration of mustard oil, and the rate of decrease was higher when time of incubation was less. Lipase activity was found to increase with increase in time of incubation for all concentration of the substrate i.e. mustard oil. Lima et al. (2003) and Kamini et al. (1998) also reported a decrease in lipase activity with increased concentration of substrate during fermentation using Penicillium aurantiogriseum and Aspergillus niger respectively. The decrease in activity of lipase with increase in mustard oil concentration could be attributed to substrate inhibition at high concentration of substrate. When the time of incubation was more the effect of substrate concentration was less which can be explained by the fact that with time the microorganism might have developed some mechanism to overcome the inhibition caused by high substrate concentration.

From Figure 5 c) it can be observed that lipase activity increases with increase in temperature and was not much affected by change in concentration of the substrate, although slight decrease in activity was observed with increase in concentration. The reason for such behaviour could be attributed to substrate inhibition at higher concentration and optimum temperature being near $35^{\circ} \mathrm{C}$, as discussed earlier.

Figure 6 shows the effect of different culture conditions investigated on the variation in biomass of A. aculeatus during lipase production. The effect of interaction of time and temperature on growth of A. aculeatus is shown in Figure 6 a). It was observed that when time of incubation was less biomass increased with increase in temperature. The rate of increase in biomass was initially more and became almost constant with further increase in temperature. A similar pattern was observed with time of incubation as well. At low incubation temperature the rate of increase of biomass was more as compared to when the temperature of incubation was high. When the temperature or the time of incubation were high, it was found that initially the biomass increased with increase in incubation temperature and time up to a certain point, and then it started decreasing with further increase in incubation temperature and time. 
Table 1 Values of lipase activity and biomass for carious experimental conditions

\begin{tabular}{lccccc}
\hline Sl. No. & Temperature, $\mathbf{T}\left({ }^{\circ} \mathbf{C}\right)$ & Time, $\mathbf{t}(\mathbf{h})$ & $\begin{array}{c}\text { Concentration of } \\
\text { mustard oil, } \mathbf{C}(\boldsymbol{\%})\end{array}$ & $\begin{array}{c}\text { Lipase Activity } \\
(\mathbf{U} / \mathbf{m l})\end{array}$ & $\begin{array}{c}\text { Biomass } \\
(\mathbf{m g} / \mathbf{m l})\end{array}$ \\
\hline 1 & 25 & 120 & 3 & 5.32 & 270 \\
2 & 25 & 168 & 1 & 5.83 & 432 \\
3 & 25 & 168 & 5 & 5.41 & 434 \\
4 & 25 & 216 & 3 & 5.58 & 466 \\
5 & 30 & 120 & 1 & 6.33 & 457 \\
6 & 30 & 120 & 5 & 5.98 & 486 \\
7 & 30 & 168 & 3 & 6.33 & 554 \\
8 & 30 & 168 & 3 & 6.41 & 581 \\
9 & 30 & 168 & 3 & 6.39 & 566 \\
10 & 30 & 168 & 3 & 6.2 & 595 \\
11 & 30 & 168 & 3 & 5.98 & 624 \\
12 & 30 & 216 & 1 & 6.67 & 632 \\
13 & 30 & 216 & 5 & 6.52 & 577 \\
14 & 35 & 120 & 3 & 8.48 & 549 \\
15 & 35 & 168 & 1 & 9.01 & 539 \\
16 & 35 & 168 & 5 & 8.78 & 601 \\
17 & 35 & 216 & 3 & 9.52 & 552 \\
\hline
\end{tabular}

Table 2 Analysis of variance (ANOVA) for the experimental data of lipase activity and biomass

\begin{tabular}{|c|c|c|c|c|c|c|}
\hline \multirow[b]{2}{*}{ Source } & \multicolumn{3}{|c|}{ Lipase Activity } & \multicolumn{3}{|c|}{ Biomass } \\
\hline & $\begin{array}{c}\text { Sum of } \\
\text { Squares }\end{array}$ & F-Value & p-value & $\begin{array}{c}\text { Sum of } \\
\text { Squares }\end{array}$ & F-Value & $p$-value \\
\hline Model & 27.91 & 114.87 & $<0.0001^{*}$ & 127801.4 & 17.87 & $0.0005^{*}$ \\
\hline $\mathrm{T}$ & 23.29 & 862.81 & $<0.0001^{*}$ & 51040.13 & 64.23 & $<0.0001^{*}$ \\
\hline $\mathrm{t}$ & 0.59 & 22.01 & $0.0022^{*}$ & 27028.13 & 34.01 & $0.0006^{*}$ \\
\hline $\mathrm{C}$ & 0.16 & 6.12 & $0.0425^{*}$ & 180.5 & 0.23 & $0.6482 \mathrm{~ns}$ \\
\hline$T \times t$ & 0.15 & 5.63 & $0.0493 *$ & 9312.25 & 11.72 & $0.0111^{*}$ \\
\hline $\mathrm{T} \times \mathrm{C}$ & 0.01 & 0.33 & $0.5812 \mathrm{~ns}$ & 900 & 1.13 & $0.3226 \mathrm{~ns}$ \\
\hline $\mathrm{t} \times \mathrm{C}$ & 0.01 & 0.37 & $0.5620 \mathrm{~ns}$ & 1764 & 2.22 & $0.1799 \mathrm{~ns}$ \\
\hline $\mathrm{T}^{2}$ & 3.58 & 132.81 & $<0.0001 *$ & 27370.1 & 34.44 & $0.0006^{*}$ \\
\hline$t^{2}$ & 0.01 & 0.25 & $0.6306 \mathrm{~ns}$ & 8197.96 & 10.32 & $0.0148^{*}$ \\
\hline $\mathrm{C}^{2}$ & 0.02 & 0.82 & $0.3938 \mathrm{~ns}$ & 14.8026 & 0.02 & $0.8953 \mathrm{~ns}$ \\
\hline Residual & 0.19 & & & 5562.75 & & \\
\hline Lack of Fit & 0.06 & 0.66 & $0.6175 \mathrm{~ns}$ & 2608.75 & 1.18 & $0.4230 \mathrm{~ns}$ \\
\hline Pure Error & 0.12 & & & 2954 & & \\
\hline Corr Total & 28.10 & & & 133364 & & \\
\hline $\mathrm{R}^{2}$ & & 0.99 & & & 0.96 & \\
\hline Adjusted $\mathrm{R}^{2}$ & & 0.98 & & & 0.91 & \\
\hline Predicted $\mathrm{R}^{2}$ & & 0.96 & & & 0.65 & \\
\hline Adequacy Precision & & 32.05 & & & 15.70 & \\
\hline
\end{tabular}

*- Terms significant at $p<0.05$

ns- Terms not significant

Vargas et al. (2008) also observed a decrease in biomass during production of lipase by Penicillium simplicissimum. From these observations it can be inferred that the temperature and time of incubation for achieving maximum biomass was close to but less than $35^{\circ} \mathrm{C}$ and $216 \mathrm{~h}$ respectively.

The effect of interaction of concentration and time is depicted in Figure 6 b). The biomass was found to increase with increase in time of incubation. The rate of increase was more when time of incubation was less and gradually slowed as the time was increased beyond a certain point, i.e. after a certain time the biomass did not increase and remained almost constant. The variation in biomass with time was observed to be more when the concentration of mustard oil i.e. substrate source was less as compared to when the substrate concentration was more. Higher variation in biomass with time at lower concentration of substrate could be attributed to the fact that when the substrate concentration was low, the broth was dilute and the microorganism could not get sufficient time to reach the substrate at lower incubation time. But when the substrate concentration was high it became easily accessible to the microorganism for growth and higher biomass was achieved even at lesser incubation time. The biomass production was found to increase with increase in concentration of substrate when the time of incubation was less i.e. $120 \mathrm{~h}$, but as the time of incubation was more, a decrease in biomass production was noticed with increase in concentration of substrate. A decrease in biomass production with substrate concentration at higher incubation time might be due to the death of microorganisms at high substrate concentration. When the time of incubation was sufficiently high, substrate inhibition may cause death of the microorganism, thereby reducing the biomass.

From Figure 6 c) it can be observed that biomass increased with increase in temperature till $32^{\circ} \mathrm{C}$ and then decreased with further increase in temperature for all values of substrate concentration. It was also noticed that biomass production decreased with increase in concentration of substrate at lower temperatures and increase with increase in substrate concentration at higher temperature. This type of behaviour shows that low temperature i.e. $25^{\circ} \mathrm{C}$ and high concentration of mustard oil is not favourable for growth of A. aculeatus. When the temperature was near $35^{\circ} \mathrm{C}$, slight increase in biomass was observed with increase in substrate concentration. From this observation it can inferred that the optimum temperature for growth of A. aculeatus is near $35^{\circ} \mathrm{C}$.

(a)

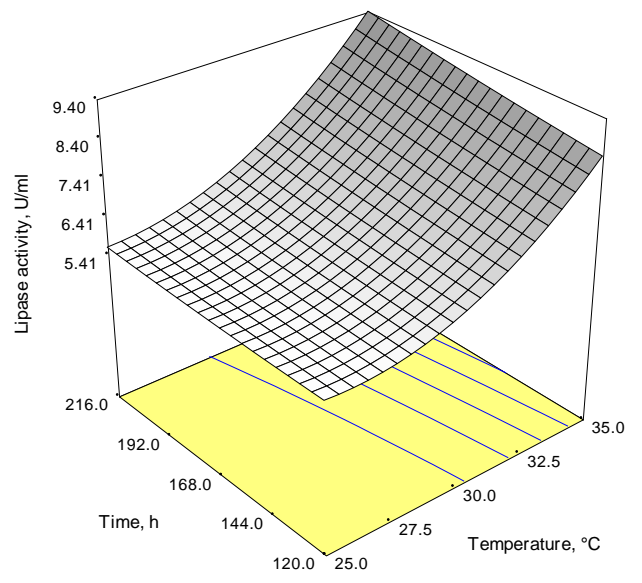


(b)

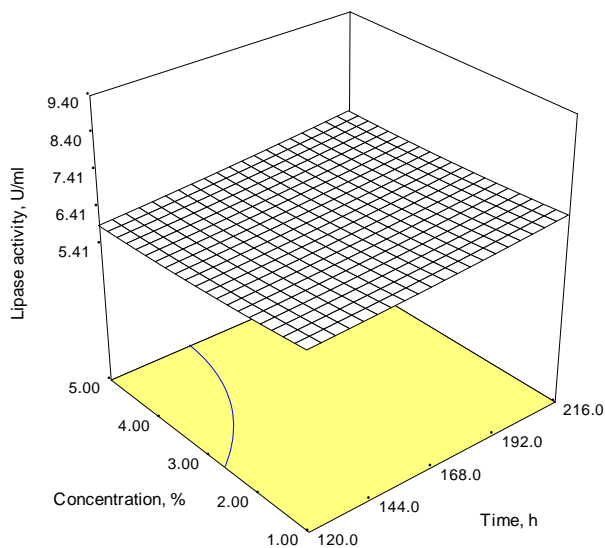

(c)

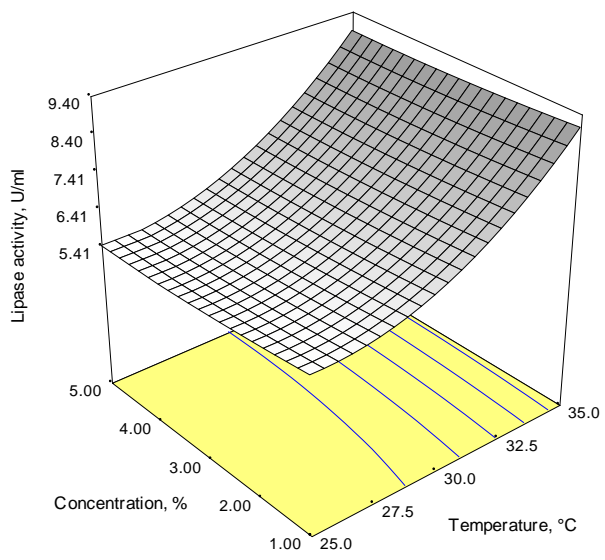

Figure 5 Effect of interaction of (a) time and temperature (b) concentration and time, and (c) concentration and temperature on lipase activity

(a)

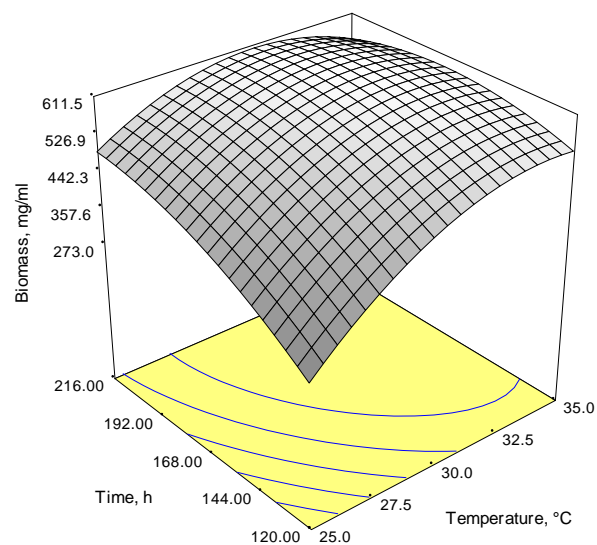

(b)

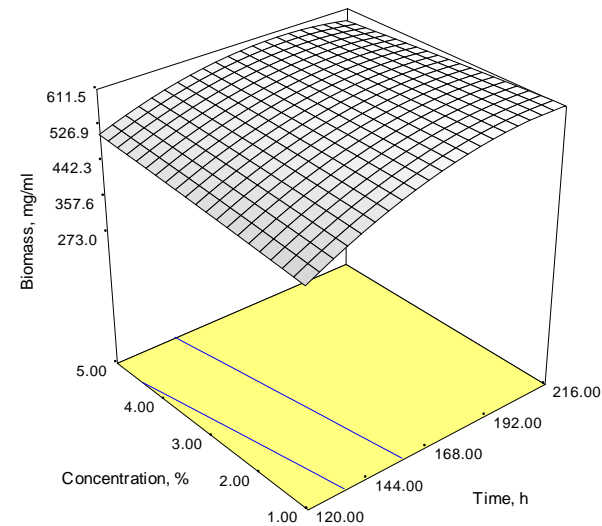

(c)

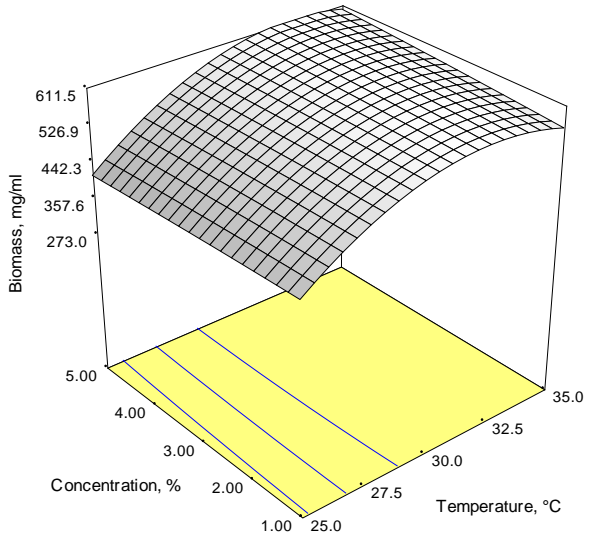

Figure 6 Effect of interaction of (a) time and temperature, (b) concentration and time and (c) concentration and temperature on biomass

\section{Optimization of culture conditions for production of lipase and validation}

Optimization of culture conditions for production of lipase was done numerically using desirability function that aimed at finding the values of process variables which would give maximum lipase activity and biomass. As the main aim of growing the microorganism was to produce lipase, therefore, lipase activity was given higher importance than biomass production while optimization. One solution with highest desirability was selected (Table 3). The optimum culture condition with maximum lipase activity of $9.51 \mathrm{U} / \mathrm{ml}$ and biomass of 549.88 was obtained when mustard oil concentration was $1 \%$, temperature of incubation was $35{ }^{\circ} \mathrm{C}$ and incubation time was $214.74 \mathrm{~h}$. For validation of optimization result experiment were conducted at the optimum culture conditions. The experimental values obtained for lipase activity and biomass were $9.33 \mathrm{U} / \mathrm{ml}$ and $496 \mathrm{mg}$. The percentage error between the actual and predicetd values for lipase activity was $1.8 \%$ and for biomass it was $9.7 \%$ which are within the acceptable range (Qi et al., 2009).

Table 3 Numerical solution of optimization and validation of optimization result

\begin{tabular}{|c|c|c|c|c|c|c|c|c|c|c|c|c|}
\hline \multirow[b]{2}{*}{$\begin{array}{l}\text { S1. } \\
\text { No. }\end{array}$} & \multirow{2}{*}{$\begin{array}{c}\text { Temperatur } \\
\text { e of } \\
\text { incubation, } \\
{ }^{\circ} \mathrm{C}\end{array}$} & \multirow{2}{*}{$\begin{array}{c}\text { Time of } \\
\text { incubation, } \\
h\end{array}$} & \multirow{2}{*}{$\begin{array}{c}\text { Concentration } \\
\text { of mustard oil, } \\
\%\end{array}$} & \multicolumn{2}{|c|}{$\begin{array}{l}\text { Optimization result } \\
\text { (Predicted) }\end{array}$} & \multicolumn{2}{|c|}{$\begin{array}{c}\text { Experimental Result } \\
\text { (Actual) }\end{array}$} & \multicolumn{2}{|c|}{ Residual } & \multicolumn{2}{|c|}{ Percent error, $\%$} & \multirow[b]{2}{*}{ Desirability } \\
\hline & & & & $\begin{array}{c}\text { Lipase } \\
\text { Activity, } \\
\text { U/ml }\end{array}$ & $\begin{array}{c}\text { Biomass, } \\
\text { mg }\end{array}$ & $\begin{array}{c}\text { Lipase } \\
\text { Activity } \\
\text {, U/ml }\end{array}$ & $\begin{array}{c}\text { Biomass, } \\
\text { mg }\end{array}$ & $\begin{array}{c}\text { Lipase } \\
\text { Activity }\end{array}$ & Biomass & $\begin{array}{l}\text { Lipase } \\
\text { Activity }\end{array}$ & Biomass & \\
\hline 1. & 35 & 214.74 & 1.00 & 9.51 & 549.88 & 9.33 & 496.00 & 0.18 & 53.88 & 1.8 & 9.7 & 0.91 \\
\hline
\end{tabular}




\section{CONCLUSION}

From the present investigation it is concluded that the strain of the fungus Aspergillus aculeatus isolated from dairy waste contaminated soil can be potentially used to produce lipase and mustard oil can be used as a source of substrate for lipase production for food application and other industrial use. The results further revealed that although the biomass production decreases after a certain time and temperature, lipase continues to be produced. This knowledge can help us designing the fermentation process for lipase production in future using this isolated strain of fungus.

\section{Conflict of Interest}

The authors confirm that no part of the manuscript have been plagiarized or self plagiarized and declare no conflict of interest.

\section{REFERENCES}

Açıkel, Ü.,Erşan, M., Açıkel, Y. S., 2010. Optimization of critical medium components using response surface methodology for lipase production by Rhizopus delemar. Food Bioprod. Process., 88, 31-39. https://doi.org/10.1016/j.fbp.2009.08.003

Al-Musallam, A. (1980). Revision of the black Aspergillus species. Revision of the black Aspergillus species.Ph.D. Thesis, University of Utrecht. 1980

Aoyama, S., Yoshida, N., Inouye, S., 1988.Cloning, sequencing and expression of the lipase gene from Pseudomonas fragiIFO-12049 in E. coli.FEBS Lett. 242 36-40. https://doi.org/10.1016/0014-5793(88)80980-3

Apinis, A. E., 1963. Occurence of Thermophilous microfungi in certain alluvia soils near Nottigham. Verlag Von J. Cramer.

Colen, G., Junqueira, R. G., Moraes-Santos, T., 2006. Isolation and screening of alkaline lipase-producing fungi from Brazilian savanna soil. World J. Microbiol.Biotechnol. 22, 881-885. https://doi.org/10.1007/s11274-005-9118-9

Corzo, O., Bracho, N., Vásquez, A., Pereira, A., 2008. Optimization of a thin layer drying process for coroba slices. J. Food Eng. 85, 372-380 https://doi.org/10.1016/j.jfoodeng.2007.07.024

Dutra, J. C., Terzi, S. D. C., Bevilaqua, J. V., Damaso, M. C., Couri, S., Langone, M. A., Senna, L. F., 2008. Lipase production in solid-state fermentation monitoring biomass growth of Aspergillus niger using digital image processing. App. Biochem. Biotechnol. 147, 63-75. https://doi.org/10.1007/9781-60327-526-2_41

Falony, G., Armas, J. C., Mendoza, J. C. D., Martínez Hernández, J. L., 2006. Production of extracellular lipase from Aspergillus niger by solid-state fermentation. Food Technol. Biotechnol. 44, 235-240.

Fan, Y., Shang, L., Qian, J., 2013. Screening, identifying and medium optimization of a lipase-producing filamentous fungus from soil for high chira resolution of 1-phenylethanol. Afr. J. Microbiol. Res. 7, 42354243. https://doi.org/10.5897/AJMR2012.2333

Glasel, J. A., 1995. Validity of nucleic acid purities monitored by $260 \mathrm{~nm} / 280 \mathrm{~nm}$ absorbance ratios. Biotechniq. 18, 62-63.

Griebeler, N., Polloni, A. E., Remonatto, D., Arbter, F., Vardanega, R., Cechet, J. L., Luccio, M. D., de Oliveira, D., Treiche, H., Cansian, R. L., Rigo, E., Ninow, J. L., 2011. Isolation and screening of lipase-producing fungi with hydrolytic activity. Food Bioprocess Technol. 4, 578-586. https://doi.org/10.1007/s11947008-0176-5

Haber, A., Runyon, R. P., 1977. General statistics. ${ }^{\text {rd }}$ Ed. Addison-Wesley Longman, UK

Hosseinpour, M. N., Najafpour, G. D., Younesi, H., Khorrami, M., Vaseghi, Z., 2012. Lipase production in solid state fermentation using Aspergillus niger: Response surface methodology. Int. J. Eng. 25, 151-159. doi: 10.582 9/i d o s i . ij e. 2012 . 2 5.03b.01

Jensen, R. G., 1983. Detection and determination of lipase (acylglycerol hydrolase) activity from various sources. Lipids 18, 650-657. https://doi.org/10.1007/BF02534677

Kamini, N. R., Mala, J. G. S., Puvanakrishnan, R., 1998. Lipase production from Aspergillus niger by solid-state fermentation using gingelly oil cake. Process Biochem. 33, 505-511. https://doi.org/10.1016/S0032-9592(98)00005-3

Kempka, A. P., Lipke, N. L., Pinheiro, T. D. L. F., Menoncin, S., Treichel, H., Freire, D. M., Di Luccio, M., de Oliveira, D., 2008. Response surface method to optimize the production and characterization of lipase from Penicillium verrucosum in solid-state fermentation. Bioprocess. Biosyst. Eng. 31, 119-125. https://doi.org/10.1007/s00449-007-0154-8

Lima, V. M., Krieger, N., Sarquis, M. I. M., Mitchell, D. A., Ramos, L. P., Fontana, J. D., 2003. Effect of nitrogen and carbon sources on lipase production by Penicillium aurantiogriseum. Food Technol. Biotechnol. 41, 105-110. https://hrcak.srce.hr/111232

Mclaren, C. G., Bartolome, V. I., Carrasco, M. C., Quintana, L. C., Ferino, M. I. B., Mojica, J. Z., Olea, A. B., Paunlagui, L. C., Ramos, C. G., Ynalvez, M. A., 1977. Experimental design and data analysis for agricultural research, vol. 1. Los Banos. Laguna: International Rice Research Institute.
Mohapatra, D., Bal, S., 2010. Optimization of polishing conditions for long grain basmati rice in a laboratory abrasive mill. Food Bioprocess Technol. 3, 466-472 https://doi.org/10.1007/s11947-009-0254-3

Muthazhagan, K., Thangaraj, M., 2014. Production and partial characterization of lipase by Bacillus sp isolated from vellar estuary sediment. Int. J. Sci. Inv. Today. 3, 639-653.

Nwuche, C. O., Ogbonna, J. C., 2011. Isolation of lipase producing fungi from palm oil mill effluent (POME) dump sites at Nsukka. Braz. Arch.f Biol Technol. 54, 113-116. http://dx.doi.org/10.1590/S1516-89132011000100015

Qi, B., Chen, X., Shen, F., Su, Y., Wan, Y., 2009. Optimization of enzymatic hydrolysis of wheat straw pretreated by alkaline peroxide using response surface methodology. Ind. Eng. Chem. Res. 48, 7346-7353 https://pubs.acs.org/doi/abs/10.1021/ie8016863

Rajeshkumar, M. P., Mahendran, V. S., Balakrishnan, V., 2013. Isolation and identification of lipase producing organisms from diverse soil samples of Kolli hills. Int. J. Curr. Microbiol. App. Sci. 2, 205-210.

Salihu, A., Alam, M. Z., AbdulKarim, M. I., Salleh, H. M., 2011. Optimization of lipase production by Candida cylindracea in palm oil mill effluent based medium using statistical experimental design. J. Mol. Catal. B: Enzym. 69, 66-73. https://doi.org/10.1016/j.molcatb.2010.12.012

Sanger, F., Coulson, A. R., 1975. A rapid method for determining sequences in DNA by primed synthesis with DNA polymerase. J. Mol. Biol. 94, 441-448. https://doi.org/10.1016/0022-2836(75)90213-2

Sharma, R., Chisti, Y., \& Banerjee, U. C., 2001. Production, purification, characterization, and applications of lipases. Biotechnol. Adv. 19, 627-662 https://doi.org/10.1016/S0734-9750(01)00086-6

Sirisha, E., Rajasekar, N., Narasu, M. L., 2010. Isolation and optimization of lipase producing bacteria from oil contaminated soils. Adv. Biol. Res. 4, 249252.

Sivakumar, N., 2014. Production of Microbial Lipase Enzyme - Review. International Journal of Adv. Res. Biol. Sci. 1, 01-12.

Sundar, W. A., Kumaresapillai, N., 2013. Isolation, purification and medium optimization of lipase enzyme producing strains of Aspergillu sniger isolated from natural sources. Int. J. Pharm. Pharm. Sci. 5, 321-324.

Ülker, S., Özel, A., Çolak, A., Karaoğlu, S.. A., 2011. Isolation, production, and characterization of an extracellular lipase from Trichoderma harzianum isolated from soil. Turk. J. Biol. 35, 543-550. doi:10.3906/biy-1004-107

Vargas, G. D. L. P., Treichel, H., de Oliveira, D., Beneti, S. C., Freire, D. M., Di Luccio, M., 2008. Optimization of lipase production by Penicillium simplicissimum in soybean meal. J. Chem. Technol. Biotechnol. 83, 47-54 https://doi.org/10.1002/jctb.1776

Veerapagu, M., Narayanan, A. S., Ponmurugan, K., Jeya, K. R., 2013. Screening selection identification production and optimization of bacterial lipase from oil spilled soil. Asian J. Pharm. Clin. Res. 6, 62-67.

Wu, Z. H., Wang, T. H., Huang, W., Qu, Y. B., 2001. A simplified method for chromosome DNA preparation from filamentous fungi. Mycosystema 20, 575. 